\title{
Diet and serum cholesterol of lumberjacks
}

\author{
By M. J. KARVONEN, MAIJA PEKKARINEN, P. METSÄLÄ \\ AND Y. RAUTANEN \\ Institute of Occupational Health, Helsinki, Finland
}

(Received 8 February r960-Revised 18 Fanuary 196r)

The occupation of the lumberjack is known to demand an exceptionally high expenditure of energy (Tigerstedt, I900; Woods \& Mansfield, r904; Boalt \& Zotterman, I943; Lundgren \& Zotterman, I943; Alpert, Lusby \& Goodhart, I943; Gibson, I946; Pyke, I947; Karvonen \& Turpeinen, I954). In former days, the diet at the workers' camps was often unbalanced, owing to difficulties of transport, lack of adequate storage for vegetables, and poor organization. Scurvy was not uncommon (Tigerstedt, 1900). Such handicaps are no longer important; the lumberjacks have had an opportunity to develop their diets according to their needs and wishes. However, the type and amount of the physical work has remained very much the same. Even mechanization-such as the introduction of motor saws, tractors and lorrieshas not eliminated heavy manual labour from forest work.

It is known from previous studies that fat is particularly important in the lumberjack's diet. This is understandable, since fat is the most concentrated source of calories; at the very high energy-expenditure levels, it would be physically difficult to eat sufficient volumes of foods with low calorie value. During recent years, increasing attention has been paid to diets rich in fats as a cause of high serum-cholesterol levels and, eventually, of atherosclerosis. Physical activity, on the other hand, has been shown in short-term experiments to prevent the cholesterogenic action of dietary fat (Keys, Anderson \& Mickelsen, I956; Taylor, Anderson \& Keys, r957). In some groups of men doing heavy physical work the serum cholesterol is lower than in the more sedentary members of the same population, but in other populations and age classes there has been no difference (Keys, Fidanza \& Keys, 1955; Keys, Anderson, Aresu, Biörck, Brock, Bronte-Stewart, Fidanza, Keys, Malmros, Poppi, Posteli, Swahn \& del Vecchio, I956; Keys, Karvonen \& Fidanza, 1958; Gopalan \& Ramanathan, I957; Brunner \& Lobl, 1958; Karvonen, Rautanen, Rikkonen \& Kihlberg, 1958).

The purpose of the study described here was to obtain information on the diet and, at the same time, on the serum-cholesterol level of lumberjacks actively engaged in forest work. For comparison, a series of cholesterol determinations was also made among less active men in the same region. The results are compared with those of previous dietary and cholesterol studies. 


\section{EXPERIMENTAL}

Subjects. Five camps of lumberjacks in Ilomantsi, in eastern Finland, were studied during the winter of 1959 . Four of them were owned by a large timber firm, one by the State Forest Administration. From fifteen to fifty men worked in each camp. Most of them were cutting timber, others were horsemen, lorry drivers and foremen. The age range was from 15 to 66 years.

Diet. The men lived and took their meals in barracks. Those having their homes in the neighbourhood spent Sundays at home, and often missed the camp meals also on Saturdays. The barracks included a kitchen with modern equipment. One or two female cooks took care of the cooking, cleaning and laundry.

The daily meals were: 6.00-6.30, coffee; I 1.00, luncheon (usually taken in the forest); I 7.00 dinner; 19.00 coffee. In three camps situated near the barracks, men could take their midday meal in the barracks and about half did so.

The food came from two sources. The men in each barrack formed a co-operative which bought all the foodstuffs used in cooking and at the main meals. In addition, each man had his own provisions of bread and butter, and most of them also cold meats and sausage.

The morning and evening coffee were supplied with sugar and cream (or an hydrogenated vegetable-oil substitute). Some of the men ate their own provisions, but many had no food with their coffee.

The meals generally comprised two courses. The main course usually consisted of potatoes with various sauces; steak; meat, vegetable or macaroni casserole; fried fish; and meat, fish or pea soup. In addition, salt herring, beetroot salad or pickled cucumber was served. The second course was porridge or gruel made of flour or cereals; pancakes; and a sweet or berries or fruit. Milk was served with the meals. In four of the camps, the co-operative also provided the bread and butter used at the meals.

The amount of food consumed was estimated from the book-keeping records of the co-operative. The period covered was the preceding 2 or 4 weeks, depending on the interval between inventories in each camp. The amount of private provisions was estimated by interviews. The composition of the food was calculated from Finnish food composition tables (Turpeinen \& Roine, 1958). The figures for energy denote net energy available from the foods as consumed. All other figures refer to the total amount of each nutrient present in the edible portions, no deductions being made for losses during cooking or for incomplete absorption. The amount of waste was minimal; there was an obvious tendency to avoid unnecessary expenditure on food.

For the calculation of the fatty-acid composition of the diets, an unpublished table (April 1957) of analytical values from the Laboratory of Physiological Hygiene, University of Minnesota, was used, together with Peltola's (1945) analytical results for Finnish milk fat, and values obtained for Finnish margarine by the Research Division of the Miami Valley Laboratories of the Procter and Gamble Co., U.S.A.

Serum cholesterol. Blood samples were taken from I 46 subjects; I o were lumberjacks engaged in heavy physical work. Of the I Io samples from lumberjacks, twenty 
were lost owing to breakage and freezing during transport. As control material, blood samples were taken at the same time in Ilomantsi from a random sample of fifty-four men of similar age who were not engaged in forestry work.

Serum cholesterol was determined in duplicate by the method of Abell, Levy, Brodie \& Kendall (1952), as modified by Anderson \& Keys (1956).

\section{RESULTS}

Diet. The average consumption of different foods in each camp is shown in Table $\mathrm{I}$. There must be large individual variations, depending on the type and intensity of work, age, body size and so on. For the lumberjacks engaged in cutting wood, the mean values were probably a little too low. A comparison with the mean food consumption of the rural population in the same area and during the same season (Roine, Pekkarinen, Karvonen \& Kihlberg, 1958) showed that the extra energy need of lumberjacks was covered mainly by butter, meat, grain products and sugar, all of them concentrated sources of energy. These foods were important items in the private provisions of the men. The private provisions eaten daily contained on an average: $293 \mathrm{~g}$ bread, Ior $\mathrm{g}$ butter, I $55 \mathrm{~g}$ sausage or canned meat, $76 \mathrm{~g}$ sugar, $78 \mathrm{~g}$ milk or cream for the coffee, and $28 \mathrm{~g}$ cakes.

Table I. Mean amounts of major foodstuffs (g/day) consumed in five lumberjacks' camps, as compared with the average local diet

\begin{tabular}{|c|c|c|c|c|c|c|c|}
\hline Foodstuff & $\underset{I}{\text { Camp }}$ & $\underset{2}{\text { Camp }}$ & $\begin{array}{c}\text { Camp } \\
3\end{array}$ & $\begin{array}{c}\text { Camp } \\
4\end{array}$ & $\begin{array}{c}\text { Camp } \\
5\end{array}$ & $\begin{array}{c}\text { All } \\
\text { camps }\end{array}$ & $\begin{array}{c}\text { Local } \\
\text { average* }\end{array}$ \\
\hline Flour and cereals & 83 & 49 & 80 & 34 & 172 & 84 & 56 \\
\hline Bread: brown & 354 & 425 & 415 & 428 & $3 \circ 3$ & $3^{8} 5$ & 156 \\
\hline white & 2 & 4 & 85 & 70 & 85 & 49 & 136 \\
\hline Peas & 一 & 6 & 54 & II & - & 14 & 5 \\
\hline Potatoes & 500 & 500 & 268 & 332 & 209 & 362 & 220 \\
\hline Other vegetables & 33 & 105 & 172 & 68 & 17 & 79 & 23 \\
\hline Berries and fruits & 27 & 50 & 30 & - & 7 & 23 & 45 \\
\hline Sugar & $\mathrm{I} 64$ & 117 & I 39 & r 57 & 145 & 144 & 65 \\
\hline Margarine & 23 & 34 & 14 & 5 & - & I 5 & 7 \\
\hline Milk and cream & 843 & 1099 & 665 & 825 & 176 & 722 & $8 \times 5$ \\
\hline Butter & 108 & I I 5 & 125 & I34 & I 84 & I 33 & 45 \\
\hline Meat: beef & 96 & 214 & I34 & 162 & 64 & I 34 & 19 \\
\hline pork & 69 & 47 & 98 & I 2 & $5^{8}$ & 57 & 25 \\
\hline $\begin{array}{l}\text { sausage and } \\
\text { canned meat }\end{array}$ & I 84 & 236 & 2 & I 1 & 232 & I 69 & I4 \\
\hline Fish & 33 & I I & 102 & 45 & 30 & 44 & 20 \\
\hline Eggs & 31 & I 5 & 8 & - & 3 & II & 4 \\
\hline
\end{tabular}

The percentage contribution to the total calories of the various classes of foods is shown in Table 2, as compared with the corresponding figures for the Finnish rural population in $195^{6-7}$ (Roine \& Pekkarinen, 1958). The mean energy content of the daily diet was $47^{6} 3 \mathrm{kcal}$ (Table 3 ). In the lumberjacks' diet the large contribution of butter and meat products is noteworthy.

The supply of individual nutrients was in general sufficient (Table 3 ) and, with the 
exception of calcium, exceeded the mean for the local population (Roine et al. 1958). However, there was marked variation between camps. In an outlying camp close to the border of USSR, milk and vegetables were not easily obtainable and, consequently, the supply of calcium was quite low, only $473 \mathrm{mg}$ daily (according to Turpeinen $\&$ Roine (1958) the recommended daily allowance is $700 \mathrm{mg}$ ). Considering that in prolonged cooking ascorbic acid may be lost, its daily supply in this camp was marginal, $3 \mathrm{I} \mathrm{mg}$ (recommendation $30 \mathrm{mg}$ ), and that of riboflavin $(\mathrm{r} \cdot 8 \mathrm{mg}$ ) also approached the critical level (recommendation $\mathrm{I} \cdot 5 \mathrm{mg}$ ). The daily supply of iodine was in all camps below the roo $\mu \mathrm{g}$ recommended by the World Health Organization (Stanbury, 1953).

Table 2. Mean percentage contribution by major foodstuffs to total intake of calories in five lumberjacks' camps, compared with their contribution in the average local diet

$\begin{array}{lcc}\text { Foodstuff } & \text { Camps } & \begin{array}{c}\text { Local } \\ \text { average* }\end{array} \\ \text { Grain products } & 28 & 33 \\ \text { Potatoes } & 5 & 6 \cdot 5 \\ \text { Other vegetables, } & 2 & 3.5 \\ \quad \text { fruits and berries } & & \\ \text { Sugar } & \text { I2 } & \text { 10 } \\ \text { Margarine } & 2 \cdot 5 & 4.5 \\ \text { Butter } & 20 & \text { II } \\ \text { Milk and cream } & \text { I0.5 } & 22 \\ \text { Meat } & 19 & 7 \cdot 0 \\ \text { Fish and eggs } & \text { I.3 } & 2 \cdot 5 \\ \quad \text { * Roine \& Pekkarinen (1958). }\end{array}$

Table 3. Mean nutritive value/head day of diets in five lumberjacks' camps, compared with the local average diet

\begin{tabular}{|c|c|c|c|c|c|c|c|}
\hline Nutrient & $\underset{\mathrm{r}}{\text { Camp }}$ & $\underset{2}{\text { Camp }}$ & $\begin{array}{c}\text { Camp } \\
3\end{array}$ & $\begin{array}{c}\text { Camp } \\
4\end{array}$ & $\begin{array}{c}\text { Camp } \\
5\end{array}$ & $\begin{array}{c}\text { All } \\
\text { camps }\end{array}$ & $\begin{array}{c}\text { Local } \\
\text { average* }\end{array}$ \\
\hline Energy (kcal) & 4573 & 5016 & 4830 & 4704 & 4690 & 4763 & $273^{2}$ \\
\hline $\begin{array}{l}\text { Protein }(\mathrm{g}) \\
\text { Fat }(\mathrm{g}) \\
\text { Carbohydrate }(\mathrm{g})\end{array}$ & $\begin{array}{l}122 \\
228 \\
539\end{array}$ & $\begin{array}{l}154 \\
265 \\
539\end{array}$ & $\begin{array}{l}133 \\
218 \\
620\end{array}$ & $\begin{array}{l}132 \\
228 \\
568\end{array}$ & $\begin{array}{l}120 \\
244 \\
53^{8}\end{array}$ & $\begin{array}{l}132 \\
237 \\
560\end{array}$ & $\begin{array}{r}83 \\
105 \\
376\end{array}$ \\
\hline $\begin{array}{l}\text { Calcium }(\mathrm{mg}) \\
\text { Iron }(\mathrm{mg}) \\
\text { Iodine }(\mu \mathrm{g})\end{array}$ & $\begin{array}{r}972 \\
25 \\
66\end{array}$ & $\begin{array}{r}\text { r } 591 \\
30 \\
76\end{array}$ & $\begin{array}{r}138 \\
28 \\
86\end{array}$ & $\begin{array}{r}1245 \\
26 \\
73\end{array}$ & $\begin{array}{r}473 \\
28 \\
58\end{array}$ & $\begin{array}{r}1085 \\
27 \\
72\end{array}$ & $\begin{array}{r}1219 \\
13 \\
51\end{array}$ \\
\hline $\begin{array}{l}\text { Vitamin A (i.u.)† } \\
\text { Thiamine (mg) } \\
\text { Riboflavin (mg) } \\
\text { Nicotinamide (mg) } \\
\text { Ascorbic acid (mg) }\end{array}$ & $\begin{array}{r}4545 \\
2 \cdot 5 \\
3 \cdot 2 \\
2 I \\
86\end{array}$ & $\begin{array}{r}5732 \\
2 \cdot 8 \\
4.0 \\
27 \\
109\end{array}$ & $\begin{array}{c}5578 \\
2 \cdot 5 \\
2 \cdot 8 \\
19 \\
73\end{array}$ & $\begin{array}{r}4976 \\
3^{\circ} \circ \\
3^{\cdot} \\
22 \\
73\end{array}$ & $\begin{array}{r}5502 \\
2 \cdot I \\
I \cdot 8 \\
22 \\
3 I\end{array}$ & $\begin{array}{c}5257 \\
2 \cdot 6 \\
3 \cdot 0 \\
22 \\
72\end{array}$ & $\begin{array}{c}2820 \\
I \cdot 7 \\
2 \cdot 5 \\
14 \\
54\end{array}$ \\
\hline
\end{tabular}

Table 4 gives detailed information on the use of fats. The mean consumption of fat was high, $237 \mathrm{~g} /$ day. The contribution of fat to total calories was high, $45 \%$, compared with the mean for the local population ( $35 \%$ ). Of the fat, almost $60 \%$ was from milk and butter, about $30 \%$ from meat, and $5 \%$ from margarine. Saturated fatty acids were predominant and the amount of linoleic acid and other polyenoic 
fatty acids was rather small. The ratio, saturated:polyenoic fatty acids, was $7 \cdot 5$, i.e. similar to that in the average diet of the local population (Roine et al. 1958).

Serum cholesterol. Table 5 shows the mean serum-cholesterol level for each decade of age between 20 and 59 years. Men outside this age range were so few (seven lumberjacks and eight controls) that values for them are not presented. The mean values for the lumberjacks were close to those of other local men: before 30 they were slightly

Table 4. Mean amounts of, and energy derived from, fats in the diets in five lumberjacks' camps, compared with the average local diet

\begin{tabular}{|c|c|c|c|c|c|c|c|}
\hline Item & $\underset{\mathbf{I}}{\text { Camp }}$ & $\underset{2}{\text { Camp }}$ & $\begin{array}{c}\text { Camp } \\
3\end{array}$ & $\underset{4}{\text { Camp }}$ & $\begin{array}{c}\text { Camp } \\
5\end{array}$ & $\begin{array}{c}\text { All } \\
\text { camps }\end{array}$ & $\begin{array}{l}\text { Local } \\
\text { average* }\end{array}$ \\
\hline Fats (g/day) & 228 & 265 & $2 \mathrm{I} 8$ & 228 & 244 & 237 & 105 \\
\hline \multicolumn{8}{|l|}{ Fatty acids (g/day): } \\
\hline Saturated & 117.5 & I3 $8 \cdot 8$ & II $3 \cdot 2$ & 120.9 & 130.9 & $124 \cdot 2$ & $5^{6 \cdot 5}$ \\
\hline Monoenoic & $82 \cdot 0$ & $95^{\cdot} \mathbf{I}$ & $75 \cdot 8$ & $80 \cdot 1$ & $87 \cdot 1$ & $85^{\circ} 0$ & 35.5 \\
\hline Linoleic & I $5 \cdot 1$ & $16 \cdot 8$ & I $4 \cdot 1$ & I 3.0 & 12.9 & I $4: 5$ & 6.8 \\
\hline Other polyenoic & $2 \cdot 1$ & $2 \cdot 1$ & $3 \cdot 7$ & $1 \cdot 5$ & $x \cdot 2$ & $2 \cdot 1$ & $I \cdot 2$ \\
\hline \multicolumn{8}{|l|}{$\begin{array}{l}\text { Percentage of total } \\
\text { energy value of diets } \\
\text { from: }\end{array}$} \\
\hline All fats & $44 \cdot 9$ & $47 \cdot 6$ & $40 \cdot 6$ & $43 \cdot 6$ & $46 \cdot 8$ & $44 \cdot 7$ & $34 \cdot 6$ \\
\hline Saturated fatty acids & $23 \cdot 1$ & $24 \cdot 9$ & $21 \cdot I$ & $23^{*} I$ & $25 \cdot I$ & $23 \cdot 5$ & $18 \cdot 2 \dagger$ \\
\hline Linoleic and other & $3 \cdot 4$ & $3 \cdot 4$ & $3 \cdot 3$ & $2 \cdot 8$ & $2 \cdot 7$ & $3 \cdot 1$ & $2 \cdot 6 \dagger$ \\
\hline
\end{tabular}

* Roine et al. (1958). † Calculated from data of Roine et al. (1958).

Table 5. Mean values with their standard errors for serum cholesterol of active lumberjacks compared with those for other local men

\begin{tabular}{|c|c|c|c|c|}
\hline Group & $20-29$ years & $30-39$ years & $40-49$ years & $50-59$ years \\
\hline Lumberjacks, winter 1959 & $\frac{246 \pm 10.8}{(25)}$ & $\begin{array}{c}256 \pm 8 \cdot 6 \\
(24)\end{array}$ & $\begin{array}{c}266 \pm \text { I } 3 \cdot 9 \\
\text { (I })\end{array}$ & $\begin{array}{c}274 \pm 10 \cdot 3 \\
(15)\end{array}$ \\
\hline Other men: winter 1959 & $\begin{array}{c}217 \pm 23 \cdot 9 \\
(6)\end{array}$ & $\begin{array}{l}273 \pm 17 \cdot 0 \\
(10)\end{array}$ & $\underset{(\mathrm{I} 5)}{27 \pm \pm x \cdot 8}$ & $\begin{array}{c}287 \pm 16 \cdot 8 \\
\left(\mathrm{I}_{5}\right)\end{array}$ \\
\hline $\begin{array}{l}\text { on light work, } \\
\text { autumn } 1956 \\
\text { (Keys et al. 1958) }\end{array}$ & $\frac{226 \pm 9^{\cdot 1}}{(28)}$ & $\begin{array}{c}276 \pm \text { I I } \cdot 8 \\
(24)\end{array}$ & $\begin{array}{c}286 \pm I I \cdot I \\
(24)\end{array}$ & $\begin{array}{l}25^{8} \pm I 4^{\cdot I} \\
(I 4)\end{array}$ \\
\hline $\begin{array}{l}\text { on heavy work, } \\
\text { autumn 1956 } \\
\text { (Keys et al. 1958) }\end{array}$ & $\frac{215 \pm 6 \cdot 9}{(40)}$ & $\frac{263 \pm 8 \cdot 0}{(57)}$ & $\begin{array}{c}25 \mathrm{I} \pm 5^{\circ} 9 \\
(57)\end{array}$ & $\begin{array}{c}252 \pm 7 \cdot 6 \\
(3 I)\end{array}$ \\
\hline
\end{tabular}

Figures in parentheses show the number of men in a group.

above, and after that somewhat below. In age groups other than $30-39$ years, the mean cholesterol level of the lumberjacks tended to exceed that of those local men engaged in heavy manual work who had been examined in the autumn of 1956 ; this finding agrees with the direction of seasonal variation of the cholesterol level in the local population (Keys et al. 1958). The differences between the groups were relatively small, and did not attain statistical significance in any of the age groups.

With advancing age, the mean serum-cholesterol level of the lumberjacks rose steadily, at the rate of $\mathrm{I} \mathrm{mg} / 100 \mathrm{ml}$ year. 


\section{DISCUSSION}

The amount of fat eaten by the lumberjacks was unusually large, more than $200 \mathrm{~g}$ a day. The assumption of a linear correlation between the amount of fat eaten and the serum-cholesterol level (Keys, Anderson \& Grande, I957a,b) would lead one to expect that the lumberjacks' serum-cholesterol levels would be much higher than those of other men in the same area, far above $300 \mathrm{mg} / 100 \mathrm{ml}$. However, there was almost no difference in cholesterol content, although both the amount of fat and its percentage contribution to the total calories differed markedly. This result may be explained in one of two ways. Either (x) the serum-cholesterol level of the local population represents a maximum which cannot be pushed higher by any increase in the consumption of fat, or (2) the expected rise in cholesterol content was prevented by the heavy work of the lumberjacks. The first explanation could easily be shown to be invalid if populations with higher mean serum-cholesterol levels were known to exist; but so far, hardly any populations have been found to have a mean cholesterol level exceeding that of the rural men in eastern Finland. The second explanation has, however, much to recommend it. It has been shown that the serum-cholesterol level of champion skiers is significantly lower than that of similar men in the general population (Karvonen et al. 1958). The study now described completes the picture obtained from earlier work in so far as both the serum-cholesterol level and the diet of this highly active group were examined.

In several populations, men engaged in heavy work obtain most of their extra calories from sources other than fat, with a resulting smaller percentage contribution of fat calories (Keys et al. 1955; Keys, Anderson, Aresu et al. 1956). In such groups, the serum-cholesterol level may be lower than that of a less active population, simply owing to a difference in diet, and no conclusion can be drawn as to the effect of the type of work on cholesterol level. The lumberjacks, however, are an exception: they obtain a higher percentage of their calories from fat than does the general population, and thus provide strong evidence for the second explanation.

From the point of view of public health, the serum-cholesterol values of the lumberjacks were at levels at which, according to experience gained from several studies, the risk of clinical manifestations of atherosclerosis increases. In the Framingham study (Dawber, Moore \& Mann, I957; Moore \& Page, 1958), a limit drawn at $260 \mathrm{mg} /$ I00 $\mathrm{ml}$ gave a clear separation between low and high individual risk of atherosclerotic heart disease. There were many men in the high-risk zone among the lumberjacks even below the age of 30 , and from the age of 40 onwards the majority exceeded the limit of $260 \mathrm{mg} / \mathrm{r} 00 \mathrm{ml}$. However, the findings of the Framingham study may not be applicable to the lumberjacks; information on the incidence of cardiovascular disease among them is needed in order to judge whether other means in addition to heavy work should be used to lower their serum-cholesterol level.

The amount of saturated fatty acids in the diet of the lumberjacks appeared unduly large. If attempts are to be made to reduce it, the use of grain products, potatoes and other vegetables, fruits and berries should be increased, and some of the solid fats should be replaced by oils. Attention should be paid to a sufficient supply of milk to 
all camps. In order to spread the food intake more evenly, the breakfast ought to be more substantial and include some protein food.

\section{SUMMARY}

I. The consumption of food in five lumberjacks' camps in eastern Finland was estimated from the book-keeping records, and by questioning the men.

2. The mean energy value of the daily diet was $4763 \mathrm{kcal}, 45 \%$ of which was derived from fat. By comparison, the general local population obtains $35 \%$ of its calories from fat. The daily consumption of fat was $237 \mathrm{~g}$ (among the general local population $105 \mathrm{~g}), 60 \%$ being derived from milk and butter, and $30 \%$ from meat.

3. The supply of essential nutrients was in general sufficient, with the possible exception of iodine. In one camp, the supply of calcium seemed to be inadequate and the supplies of ascorbic acid and riboflavin were marginal.

4. In spite of the unusually large consumption of fat, the serum-cholesterol level of the lumberjacks was similar to that of other males in the local population. The mean rose from 246 to $274 \mathrm{mg} / 100 \mathrm{ml}$ between 20 and 59 years of age. That the serumcholesterol level was no higher was probably due to a depression of the serum cholesterol content by heavy work. Nevertheless, a large proportion of the cholesterol values was in the range where the risk of atherosclerosis is thought to be increased.

5. Suggestions for the improvement of the diet of the lumberjacks are made.

The study has been supported by a grant from the Welfare Foundation of the Lumberjacks (Metsämiesten Säätiö).

\section{REFERENCES}

Abell, L. L., Levy, B. B., Brodie, B. B. \& Kendall, F. E. (1952). F. biol. Chem. I95, 357.

Alpert, E., Lusby, R. M. \& Goodhart, R. S. (1943). Quoted in Nutrition in Industry. Studies and Reports, N.S. no. 4, p. 89 (1946). Montreal: International Labour Office.

Anderson, J. T. \& Keys, A. (1956). Clin. Chem. 2, 145.

Boalt, C. \& Zotterman, Y. (1 943). Studier $i$ Skogsbrukets Arbetslära, vol. I, p. I69. Stockholm: Industriens Utredningsinstitut.

Brunner, D. \& Lobl, K. (1958). Ann. intern. Med. 49, 732.

Dawber, T. R., Moore, F. E. \& Mann, G. V. (r957). Amer. F. Publ. Hlth, 47, no. 4, part 2, p. 4.

Gibson, D. L. (1946). Feeding in Lagging Camps. Montreal: Pulp and Paper Research Institute of Canada.

Gopalan, C. \& Ramanathan, K. S. (1957). Indian F. med. Res. 45, 593.

Karvonen, M. J., Rautanen, Y., Rikkonen, P. \& Kihlberg, J. (1958). Ann. Med. intern. Fenn. 47, 75. Karvonen, M. J. \& Turpeinen, O. (1954). F. appl. Physiol. 6, 603.

Keys, A., Anderson, J. T., Aresu, M., Biörck, G., Brock, J. F., Bronte-Stewart, B., Fidanza, F., Keys, M. H., Malmros, H., Poppi, A., Posteli, T., Swahn, B. \& del Vecchio, A. (1956). F. clin. Invest. 35, 1173 .

Keys, A., Anderson, J. T. \& Grande, F. (1957a). Lancet, 272, 787.

Keys, A., Anderson, J. T. \& Grande, F. (1957 b). Lancet, 273, 959.

Keys, A., Anderson, J. T. \& Mickelsen, O. (1956). Science, 123, 29.

Keys, A., Fidanza, F. \& Keys, M. H. (1955). Voeding, 16, 492.

Keys, A., Karvonen, M. J. \& Fidanza, F. (1958). Lancet, ii, I75.

Lundgren, N. \& Zotterman, Y. (1943). Studier i Skogsbrukets Arbetslära, vol. 1, p. 155. Stockholm: Industriens Utredningsinstitut.

Moore, F. E. \& Page, I. H. (1958). Int. Congr. Cardiol. III. Brussels. Abstracts of Symposia, p. $3^{81 .}$ Peltola, E. (1945). Meijerit. Aikakausk. no. I-2. 
Pyke, M. (1947). F. Amer. diet. Ass. 23, 90.

Roine, P. \& Pekkarinen, M. (1958). Kotitalous, 22, 9.

Roine, P., Pekkarinen, M., Karvonen, M. J. \& Kihlberg, J. (1958). Lancet, ii, 173.

Stanbury, J. B. (1953). Chron. World Hlth Org. 7, 61.

Taylor, H. L., Anderson, J. T. \& Keys, A. (1957). Proc. Soc. exp. Biol., N.Y., 95, 383.

Tigerstedt, R. (1900). Hygiea, Stockh., 62, part I, p. I21.

Turpeinen, O. \& Roine, P. (I958). Ruoka-ainetaulukko, and ed. Helsinki: Otava.

Woods, C. D. \& Mansfield, E. R. (1904). Bull. U.S. Dep. Agric. Off. Exp. Sta. p. 149. 